\title{
Water Resources in the
}

Vicinity of Municipalities on the Eastern Mesabi Iron Range and the Vermilion Iron Range

\section{Northeastern Minnesota}

By R. D. COTTER, H. L. YOUNG, L. R. PETRI, and C. H. PRIOR

NATER RESOURCES OF THE MESABI AND VERMILION IRON RANGES

3EOLOGICAL SURVEY WATER-SUPPLY PAPER 1759-F

Prepared in cooperation with the Minnesota Department of Iron Range Resources and Rehabilitation

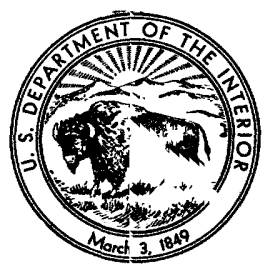




\section{UNITED STATES DEPARTMENT OF THE INTERIOR}

STEWART L. UDALL, Secretary

\section{GEOLOGICAL SURVEY}

Thomas B. Nolan, Director

Library of Congress catalog card No. GS 65-311

For sale by the Superintendent of Documents, U.S. Government Printing Office Washington, D.C., 20402 


\section{CONTENTS}

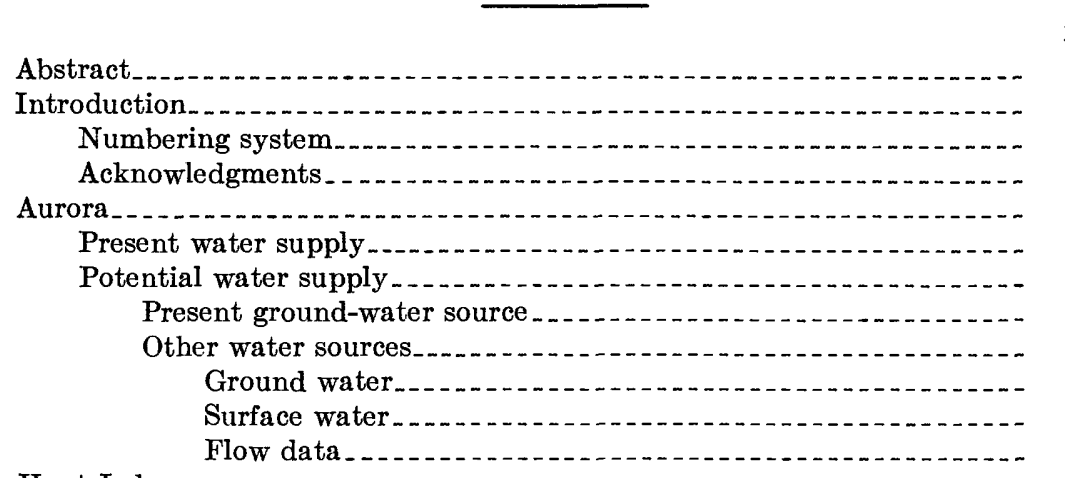

Present water supply

Potential water supply _...

Present surface-water source .......................... 12

Other water sources....... 13

Surface water

Ground water......... 13

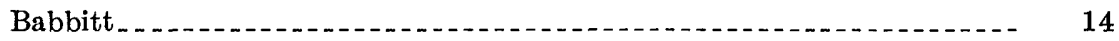

Present water supply

Potential water supply

Present ground-water source

Other water sources.............. 17

Ground water..... 17

Surface water.

Flow data

Tower-Soudan $\ldots$

Present water supply

Potential water supply

Present ground-water source

Other water sources

Ground water..... 22

Surface water

Flow data

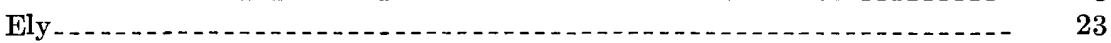

Present water supply

Potential water supply

Present surface-water source

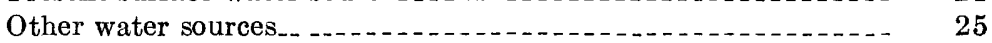

Surface water...... 25

Flow data

Ground water.... 25

Literature cited 


\section{ILLUSTRATIONS}

Plate 1. Hydrogeologic maps of municipality areas in the eastern Mesabi Iron Range and Vermilion Iron Range, northeastern Minnesota . . . . . In pocket

Frgure 1. Sketch showing method of numbering test holes and wells...-

\section{TABLES}

TABLEs 1, 2. Chemical analyses, in parts per million, of-

1. Water in the Aurora vicinity

2. The public water supply at Hoyt Lakes

3-5. Chemical analyses, in parts per million, of water in the-

3. Babbitt vicinity

4. Tower-Soudan vicinity

5. Ely vicinity 


\title{
WATER RESOURGES IN THE VICINITY OF MUNICIPALITIES ON THE EASTERN MESABI IRON RANGE AND THE VERMILION IRON RANGE, NORTHEASTERN MINNESOTA
}

\author{
By R. D. Cotrer, H. L. Young, L. R. Petri, and C. H. Prtor
}

\begin{abstract}
Additional supplies of water are available near the municipalities on the eastern Mesabi Iron Range and the Vermilion Iron Range. On the eastern Mesabi Range the potential for additional development of both groun -water and surface-water supplies are good, and on the Vermilion Range the best potential for development is from surface-water resources.

The most productive aquifers in the area of this report are the Biwabik IronFormation and the stratified glacial drift; East of Colby Lake the Riwabik Iron-Formation is not an important aquifer, and it is entirely absent on the Vermilion Range. Also, on the Vermilion Range the glacial drift is generally too thin to yield the quantities of water found on the Mesabi Range.

Surface-water supplies in the area of this report are good. An extensive network of river systems and many lakes form a large untapped pitential supply. Records of flow from eight gaging stations are presented as are data from many wells and test holes.

Ground water commonly has a high concentration of iron and mangannse and is hard. Surface water generally has a high concentration of iron and is colored. Analyses of water from many sources are included.
\end{abstract}

\section{INTRODUCTION}

This report describes existing and potential water supplies on the eastern Mesabi and Vermilion Iron Ranges, northeastern Minnesota.

Increased supplies of water are needed for expansion and diversification of the economy of the iron ranges. Specifically, supplies are needed for taconite processing, wood and peat processing, and municipal expansion. This investigation made in cooperation with the Minnesota Department of Iron Range Resources and Rehabilitation indicates that in some areas large quantities of water are available from both ground and surface sources.

The most productive aquifers are the Biwabik Iron-Formation and the stratified glacial drift. East of Colby Lake, the Biwabik is not an important aquifer. On the Vermilion Iron Range, this forma- 
tion is absent, and the glacial drift is commonly too thin to produce the quantities available on the Mesabi Range.

Bodies of stratified drift, believed by the authors to be potential sources for large ground-water supplies, are outlinet as numbered areas. Their boundaries are drawn on the basis of topography, geologic mapping, test drilling, and test pumping. The accuracy of the assessment of the ground-water supplies in each numbered area is proportional to the subsurface control.

Where adequate pumpage data are available, specific capacities of wells are noted. Multiplying the specific capacity by the maximum allowable drawdown will give the short-term maxinum yield of a well. Specific capacities decrease with an increas in time and pumping rate. Specific capacities of wells completed in artesian aquifers should not be compared with those of wells completed in water-table aquifers, because, in otherwise identical aquifers, the value obtained for a well in the artesian aquifer would be much lower.

The geologic sections in this report are based on the indicated testhole information and open-pit mine exposures. Identification of glacial deposits from drill cuttings and correlation of deposits between test holes is tenuous. However, the sections show the sequence and general lithology that probably would be penetrated in a drill hole along the line of section.

Surface-water supplies in the eastern Mesabi and Vermilion Iron Ranges are good. In the southwestern part of the area of this report, the Embarrass, St. Louis, and Partridge Rivers and Second Creek are good potential supplies. Vermilion Lake is a very large untapped potential supply in the northwest. The exstern part has a network of lakes and river systems available for utilization. Records of flow for eight gaging stations are presented.

The quality of ground water and surface water is adequate for many industrial uses. Ground water commonly has a high concentration of iron and manganese and is hard. Surface vater commonly has a high concentration of iron and is colored. Aralyses of water from many sources are included. Where no analyses have been made, tables 7 and 8 in Cotter and others (1965) can be used to approximate the quality of a potential supply.

\section{NUMBERING SYSTEM}

Identification numbers assigned to wells, test holes, or specific locations in this report also serve as the location numbers. The system of numbering is based on the U.S. Bureau of Land Manage- 


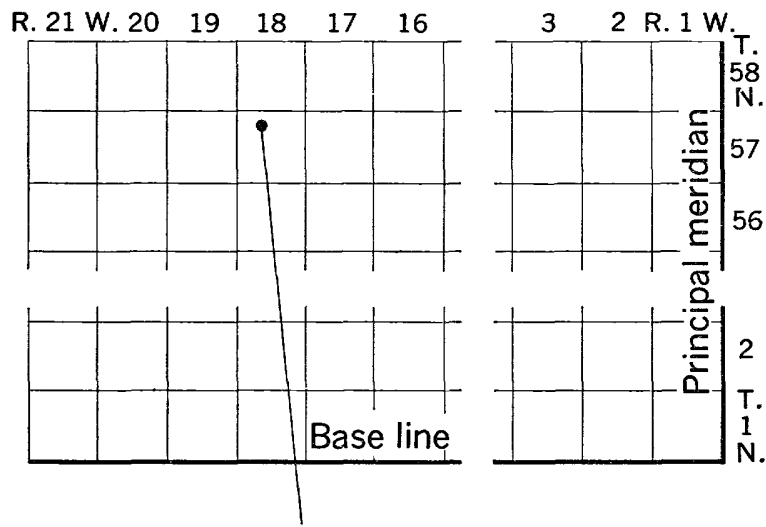

Well $57.18 .8 \mathrm{ddb} 1$

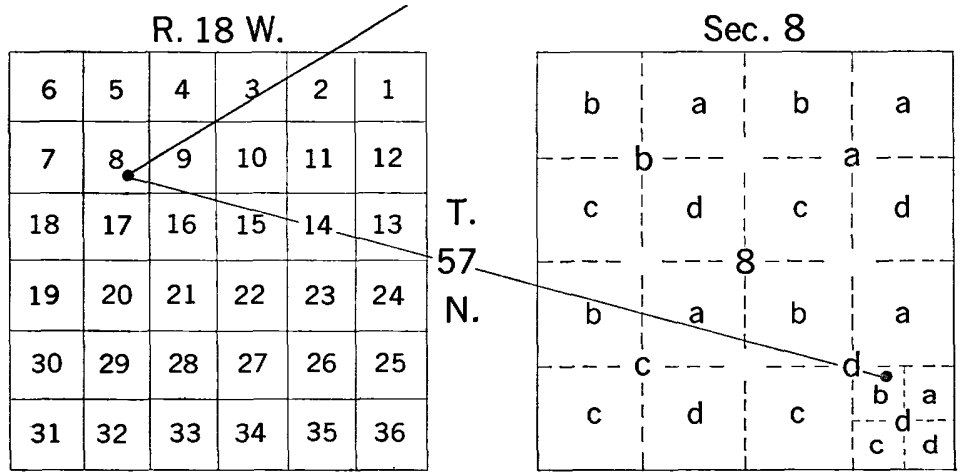

FIgURE 1.-Sketch showing method of numbering test holes and wells.

ment's system of subdivision of the public lands. Figure . illustrates the method of numbering. The number 57.18.8ddb1 idantifies the first well or test hole located in the $\mathrm{NW}^{1 / 4}, \mathrm{SE} 1 / 4, \mathrm{SE} 1 / 4$, sec. $8, \mathrm{~T}$. $57 \mathrm{~N}$., R. $18 \mathrm{~W}$. Where locations are not accurate to within 10 acres, they are identified by using only the first two lowercese letters and no number suffix.

\section{ACKNOWLEDGMENTS}

The authors acknowledge the help of municipal officials ard well drillers who contributed much of the basic data.

Mining companies in the area furnished maps and drill-hole logs and allowed examination of mine faces. W. A. Cummens, engineer of the Oliver Iron Mining Division of U.S. Steel Corp., ws particularly helpful in the ground-water phase of the investigation by furnishing current information on test drilling and other information on the hydrology of the area. 


\section{AURORA}

Population : 2,799

The village of Aurora is about 4 miles south of the Giants Range. First and Second Creeks, Partridge River, a small urnamed stream south from Aurora, and the Embarrass River drain the area to the south into the St. Louis River.

Except for the extreme northwest corner, which is underlain by Pokegama Quartzite and Ely Greenstone, the bedrock in the area is Biwabik Iron-Formation and Virginia Argillite (pl. 1). North of Aurora, in sec. 3 and 4, the Biwabik has been intruded by a syenite sill which dips to the south and is parallel to the belding (White, 1954, p. 63). The entire area is mantled by glacial drift. The drift is thin near the Giants Range but thickens to the south and west (pl. 1).

The present village water supply is obtained from two wells finished in the Biwabik Iron-Formation and the glacial drift.

\section{PRESENT WATER SUPPL $Y$}

Source of information: Herman Zuponcic, utilities superintendent.

Ownership of water supply: Municipal.

Average consumption: 250,000 gpd (gallons per day) (estimated, 1960).

Number of customers: Approximately 700 (1960).

Storage: Ground-level steel tank, 300,000 gal; elevated steel tank, 50,000 gal.

Treatment: Iron removal by aeration and gravity sand filt"ation; polyphos-

phate stabilization; addition of sodium hydroxide for $\mathrm{pH}$ adjustment;

fluoridation; chlorination.

Source of supply: Two wells.

Well location 58.15.3bcc2. One-tenth of a mile north of the St. James mine; drilled in 1957; 16 inches in diameter; 180 feet deep. Equipped with a $350 \mathrm{gpm}$ (gallons per minute) turbine pump set at $180 \mathrm{gpm}$; finished with 70 feet of 10-inch concrete screen between 40 and 160 feet; 10- and 20-foot sections of screen alternate with 10-foot blank sections. Water obtained from glacial sand and gravel between 42 and 60 feet and from Biwabik Iron-Formation between 60 and 180 feet.

Well location 58.15.3bcd1. One-tenth of a mile north of the St. James mine; an auxiliary drilled well; 6 inches in diameter and $\varepsilon ?$ feet deep; not screened; has a static water level of 20 feet below land surface. Water obtained from Biwabik Iron-Formation between 70 and 90 feet. Pumped continuously at $100 \mathrm{gpm}$ during periods of peak demand in summer months; has been pumped at $150 \mathrm{gpm}$ for 24 hours.

Quality of water.-The analysis of September 1957 represents the chemical quality of water from well $58.15 .3 \mathrm{bcc} 2$ (table 1). The water has a low dissolved-solids content and is moderately hard, but it is siliceous and contains much iron and manganese. The saturation index of -1.6 indicates that the water is corrosive. The water was clear when collected; thus, the high turbidity of $25 \mathrm{ppm}$ (parts per million) was caused by subsequent precipitation of iron and 
manganese. The water is treated for iron and manganese removal, and the turbidity is much less in the finished water.

The analysis of April 1957 indicates that treatmert then was effective in removing iron but was not effective in removing manganese. Subsequent modification in the treatment process, however, may have corrected this deficiency. Since 1957 the water has been fluoridated; consequently, the concentration of fluorjde probably is about 1 ppm.

\section{POTENTIAL WATER SUPPLY}

\section{PRESENT GROUND-WATER SOURCE}

The village wells are completed in the lower slaty nember of the Biwabik Iron-Formation, which in this area is dense fractured taconite. A fault in the Biwabik (Baxter, C., 1961, oral communication) accounts for the fracturing of the taconite. V'ell 58.15.3bcc2 reportedly obtains most of its water from glacial send and gravel overlying the iron-formation.

Both wells lie in the valley of First Creek, which haads at a notch in the Giants Range. The glacial gravel aquifer in well 58.15.3bcc2 is probably limited laterally by the sides of the praglacial stream valley. Lateral ground-water movement into the stream valley recharges the sand and gravel. Vertical drainage from the sand and gravel enters the iron-formation along fractures and voids. During the summer months both wells are operated at peal: capacity producing a total of about $225 \mathrm{gpm}$.

An 8-inch well that is 175 feet deep and is in the ore body at the Stevens mine, 3 miles northeast of Aurora, was pumped at $600 \mathrm{gpm}$ for 21 hours and had a specific capacity of $13 \mathrm{gpm}$ per foot of drawdown. Former village well 58.15.3cca1 in the ore body of the St. James mine initially was pumped at $575 \mathrm{gpm}$ and now is pumped at $250 \mathrm{gpm}$ as part of a mine-dewatering program. Two other rells also are used in dewatering this mine. Well 58.15.3cba1 pumps $100 \mathrm{gpm}$, reportedly from the syenite sill, and well 58.15.3cdb1 pumps $500 \mathrm{gpm}$ from the iron-formation.

On the south face of the St. James mine, the altered iron-formation is capped by Virginia Argillite. If further mining to the south proves uneconomical, the performance of the present wells in the St. James mine makes the area just south of the mine a promising one for the development of additional ground water. Recharge to the formation is through the overlying glacial drift over an area of several square miles, and the recharge is adequate to support a substantial increase in pumpage. 


\section{OTHER WATER SOURCES}

GROUND WATER

Logs of test holes and an inventory of domestic wells show that the three areas on the Aurora map area (pl. 1) can be considered additional sources of ground water from glacial drift.

Area 1 is underlain by thick sections of stratified drift and till. The stratified drift was deposited by glacial drainage frcm the north through the Embarrass channel. Glacial and preglacial drainage cut the Embarrass channel through the Giants Range, 2 miles north of the Embarrass mine. A buried extension of the channel cuts through the east end of the mine and as much as 275 feet of glacial deposits are exposed in the walls. The gray bouldery till is interbedded with and overlain by sand and gravel, and is underlain by as much as 100 feet of outwash sand and gravelly sand which dips to the southwest. The thickness and direction of the dip of the outwash indicate that it extends south of the mine.

Surficial and near-surface sand and gravel form the ice-contact topography in area 1 (pl. 1). These deposits are exposed in a gravel pit 0.25 mile northwest of the mine and along the north side of State Highway 135 in sec. 6. South of the highway the topography is irregular and pitted, and several auger holes drilled in sec. 7 penetrated sand and gravel immediately beneath the surface deposit of reddish-brown clayey till. (See geologic section $A-A^{\prime}$, pl. 1.) Three-quarters of a mile west of the map area, where the clayey till is buried to a depth of 98 feet, test hole 58.16 .24 bedl penetrated 79 feet of sand and gravel beneath this till. The deposition of these sediments is controlled by the shape of the upper surface of the gray bouldery till which is undoubtedly more irregular than is shown on the west end of geologic section $A-A^{\prime}$. The section is represented as sand and gravel but contains finer grained sediments.

Within area 1 a ground-water divide extends northeast from the NW1/4, sec. 18 through the SW1/4, sec. 5. Ground-water morement to the northwest is toward Embarrass Lake; to the southeast, it is toward the St. Louis River. Water levels in auger holes in sec. 7 ranged from 15 to 40 feet below the land surface.

Area 1 is underlain by a thick section of glacial deposits including permeable sand and gravel. Although details on the extent and texture of this stratified drift are not known, the area is a good potential source of ground water. 
Area 2 outlines a glacial drainage channel which contains a small stream flowing south from Aurora. The channel can be traced across the Miller pit and north of the Aurora map area, through Old Mesaba Lake to a notch in the Laurentian Divide. The glacial drainage deposited the esker train on the west side of the channel and deposited the sand and gravel found beneath the present valley floor. Several test holes in area 2 penetrate 1-30 fert of sand and gravel directly beneath the surficial reddish-brown clayey till. Saturated thicknesses of sand and gravel as much as 30 feet are known, but commonly the upper section is unsaturated. The sand and gravel is bounded on the east by finer textured outwash. (See geologic section $4-A^{\prime}$, pl. 1.) The underlying gray bouldery till is shown in the section as extending to bedrock, but in the west half of section $A-A^{\prime}$, no test holes completely penetrate the till. At the north end of area 2, test hole $58.15 .9 \mathrm{abb}$ penetrated a deep section of permeable outwash between the bouldery till at 92 feet and bedrock at 111 feet. It was pumped at 52 gpm for 6 hours and had a specific capacity of about $15 \mathrm{gpm}$ per foot of drawdown.

Regional ground-water movement is south through area 2, and recharge to the stratified drift is by vertical infiltration of precipitation and by lateral ground-water movement into the valley. The ground-water potential of the near-surface coarse stratified drift within area 2 is restricted by its slight saturated thickness. The deep sand and gravel penetrated in test hole 58.15.9abb may be capable of producing large quantities of ground water.

Area 3 crosses a southeastward-trending recessional moraine which was formed as the gray bouldery till was deposited. The moraine, which trends from the north end of Whitewater Lale to the northwest corner of sec. 2, is breached at three points: by Second Creek, Partridge River, and Colby and Whitewater Lake. The breach at the lakes is associated with the deposition of sand and gravel along the southwestward trend of area 3 . Probably the thickest and most permeable deposits within the area underlie the flat-topped highs. These highs probably resulted from deposition by glesial melt water in ice-bounded depressions south of the moraine. Test hole 58.15.24cac1, drilled atop one of these highs, penetrated 38 feet of sand and gravel below 37 feet of reddish-brown clay?y till. Within area 3, along the trace of the moraine, well-sorted to poorly sorted silty and bouldery sand and gravel is exposed at the surface.

Area 3 is a good potential source of ground water. Recharge through the surficial stratified drift is probably rapid and a con- 
siderable area of this material is in contact with Whitewater Lake because of the artificially sustained lake level. This lake lerel has produced a local "mound" on the water table (pl. 1) and numerous seeps have developed south of the lake.

Although buried channels commonly contain glacial outwash these sediments are not always good aquifers. Between areas 2 and 3 there is a buried valley that contains thick outwash (section $A-A^{\prime}$, pl. 1) ; however, the outwash is mostly fine sand and silt ard contains very little saturated sand and gravel.

\section{SURFACE WATER}

The quantities of water available from potential surface-water supplies in the vicinity of Aurora are good. On the east lie the Partridge River and Second Creek, on the south the St. Louis River, and on the west the Embarrass River (pl. 1).

Because of regulation on the St. Louis River, Partridge River, and Second Creek, no low-flow frequency curves were developed at gaging stations on these streams.

\section{FLOW DATA}

PARTRIDGE RIVER NEAR AURORA, MINN.

Location.-Lat $47^{\circ} 31^{\prime} 02^{\prime \prime}$, long $92^{\circ} 11^{\prime} 24^{\prime \prime}$, in SE1/4 SW $1 / 4$ sec. 12 , T. 58 N., R. 15 W., on right bank at upstream side of highway bridge, 1,000 feet downstream from Second Creek, 21/2 miles east of Aurora, and 23/1 miles upstream from mouth. Drainage area.-156 square miles.

Records available.-Angust 1942-September 1960.

A verage discharge.-18 years, 127 cfs (cubic feet per second) (adjusted for storage and diversion).

Extremes.-1942-60. Maximum discharge, 3,230 cfs, May 10, 1959 (gaga height, $7.86 \mathrm{ft}$ ) ; minimum, $3.1 \mathrm{cfs}$, September 22, 23, 1948, (gage height, $0.77 \mathrm{ft}$ ) ; minimum daily discharge, $3.2 \mathrm{cfs}$, September $22,23,1948$.

Flood frequency.-10-year flood, 2,050 cfs ; 20-year flood, 2,500 cfs ; 30-year flood, 2,910 cfs.

SECOND CREEK NEAR AURORA, MINN.

Location.-Lat $47^{\circ} 31^{\prime} 25^{\prime \prime}$, long $92^{\circ} 11^{\prime} 35^{\prime \prime}$, in SW1/4 sec. 12 , T. 58 N., K. 15 W., on left bank 0.1 mile downstream from First Creek, 0.4 mile upstream from mouth, and 2.1 miles east of Aurora.

Drainage area.-26.3 square miles.

Records available.-March 1955-September 1960.

Average discharge. -5 years, $16.7 \mathrm{cfs}$.

Extremes.-1955-60. Maximum discharge, $208 \mathrm{cfs}$, April 21, 1957. Maximum gage height, 5.75 feet, March 28, 1957 (backwater from ice) ; minimum discharge, $1.9 \mathrm{cfs}$. August 3, 1956 (gage height, $3.18 \mathrm{ft}$ ) ; minimum daily discharge, $2.5 \mathrm{cfs}$, February 10, 11, 11-17, $195 \mathrm{~s}$.

Flood frequency.-10-5ear flood, $48 \mathrm{cfs}$; 20-year flood, $58 \mathrm{cfs}$; 30-year floo 1,69 cfs. 
ST. LOUIS RIVER NEAR AURORA

Location.-Lat $47^{\circ} 29^{\prime} 30^{\prime \prime}$. long $92^{\circ} 14^{\prime} 20^{\prime \prime}$, in SW1/4 sec. 22 , T. 58 N., R. 15 W.. on left bank at upstream side of highway bridge, three-quarters of a mile downstream from Partridge River and $1 \frac{1}{2}$ miles south of Aurora.

Drainage area.-312 square miles.

Records available.-August 1942-September 1960.

Average discharge.-18 years. 244 cfs (adjusted for storage and dirersion).

Extremes.--1912-60. Maximum discharge, 5,380 cfs, May 14, 1960 (gage height, $8.37 \mathrm{ft}$ ) ; minimum, $4.0 \mathrm{cfs}$, October $2,3,1948$ (gage height, $0.30 \mathrm{ft}$ ) ; minimum daily discharge, 4.4 cfs, October 2, 3, 1948.

Flood frequency.-10-year flood, 2,700 cfs; 20-year flood, 3,300 cfs ; 30-year flood, $3.890 \mathrm{cfs}$.

\section{EMBARRASS RIVER NEAR MCKINLEY}

Location.-Lat $47^{\circ} 27^{\prime} 10^{\prime \prime}$, long $92^{\circ} 23^{\prime} 00^{\prime \prime}$, in NW1/4 sec. 4 , T. 57 N., R. 16 W., on left bank 40 feet upstream from highway bridge, 0.9 mile downstream from outlet of Esquagama Lake, $41 \frac{1}{2}$ miles southeast of McKinley.

Drainage area. -171 square miles.

Records a vailable.--October 1953-September 1960.

Average discharge.- 7 years, 109 cfs.

Extremes.-1953-60. Maximum discharge, 1,690 cfs, April 20, 1.954 (gage height, $11.72 \mathrm{ft}$ ) ; minimum, 11 cfs, September 7, 1955 ; minimum gage height, 2.66 feet, June 26, 1959; minimum daily discharge, 12 cfs, Septemher 6, 7, 1955.

Flood frequency.-10-year flood, 1.570 cfs ; 20-year flood, 1,190 cfs ; 30-year flood, 2,260 cfs.

Low-flow frequency.-Annual 7-day minimum discharge, 2-year, 20 efs ; 10-year, 15 cfs ; 20-year, 12 cfs.

Quality of water.-The chemical quality of water from each of the four potential surface supplies is indicated by data in table 1. Daily records show that the dissolved-solids content and hardness of water from each of the four streams fluctuate with the seasons and normally are greatest in winter and early spring. The average dissolved-solids content is slightly less for the Embarrass, Partridge, and St. Louis Rivers and is slightly more for Second Creek than the $123 \mathrm{ppm}$ of the present water supply. Hardness of the water exceeds $60 \mathrm{ppm}$ about 15 percent of the time for the Embarrass River, about 30 percent of the time for the St. Louis River, about 45 percent of the time for the Partridge River, and about 99 percent of the time for Second Creek. Iron is present in objectionable concentrations in water from each of the streams; however, these concentrations are considerably less than the concentration in water from the present ground-water source. Manganese is practically absent in water from each of the streams except Second Creek. 
Water from each of the streams has much color, but that from Second Creek has only about half as much as the other three streams.

\section{HOYT LAKES}

Population : 3,186

The village of Hoyt Lakes is the newest Iron Range municipality, having been built since 1950 to serve the taconite industry on the eastern Mesabi Range. It is about 51/2 miles south of the Giants Range. Surface drainage is to the south by way of the Partridge River into the St. Louis River which lies just south of the Hoyt Lakes map area.

The area is underlain by bedrock composed of Virginia Argillite and intrusives of the Duluth Gabbro Complex (pl. 1). Glacir.1 drift overlies the bedrock and thickens to the west. (Geologic section $A-A^{\prime}$, pl. 1). The village water supply is obtained from Colby Lake.

\section{PRESENT WATER SUPPLY}

Source of information: Urko Kesti, water and sewage plant operator; Minnesota Department of Health records.

Ownership of water supply: Municipal.

Number of customers: $700(\mathbf{1 9 6 0 )}$.

Arerage consumption: $240,000 \mathrm{gpd}(\mathbf{1 9 6 0 )}$.

Storage: Concrete reservoir, 157,500 gal; standpipe, 1,660,000 gal.

Treatment: Prechlorination; coagulation with sodium aluminate and al"minum sulfate; sedimentation: filtration; addition of sodium carbonate for $\mathrm{pH}$ adjustment; addition of activated carbon in summer for taste and color control ; postchlorination.

Source of supply: Colby Lake. Pumping station, on south side of Colby Lake (58.14.8bda), is equipped with three pumps having capacities of 375,500 , and $700 \mathrm{gpm}$. An 18-inch intake pipe extends 230 feet into lake. From the point of intake, 26 feet below lake level, water flows by gravity to an intake. well at pumping station.

Quality of water.-Water from Colby Lake is soft and is low in dissolved-solids content (see table 2). However, it is modorately siliceous, has much iron and manganese, and is highly colored. Treatment greatly reduces the color of the water and lowers the iron and manganese content, but the addition of aluminum suffate increases the sulfate content. The saturation index of the raw water was -2.4 on April 17, 1958; the addition of sodium carbonate to the water aids in controlling corrosion. 
TABLE 2.-Chemical analyses, in parts per million, of public water supply at Hoyt Lakes

[Analysis of sample collected Apr. 17, 1958, by U.S. Geol. Survey; remainder by the Minnesota Dept. of Health]

\begin{tabular}{|c|c|c|c|}
\hline $\begin{array}{l}\text { Water source.- } \\
\text { Location }\end{array}$ & $\begin{array}{l}\text { Colby Lake } \\
58.14 .8 \mathrm{bda}\end{array}$ & Finished & $\begin{array}{l}\text { Colby Lake } \\
\text { 58.14.8bda }\end{array}$ \\
\hline $\begin{array}{l}\text { Silica }\left(\mathrm{SiO}_{2}\right) \\
\text { Iron }(\mathrm{Fe}) \\
\text { Manganese }(\mathrm{Mn})\end{array}$ & $\begin{array}{r}4.1 \\
.23\end{array}$ & $\begin{array}{r}0.88 \\
.18\end{array}$ & $\begin{array}{r}11 \\
.95 \\
.10\end{array}$ \\
\hline $\begin{array}{l}\text { Calcium }(\mathrm{Ca}) \\
\text { Magnesium }(\mathrm{Mg}) \\
\text { Sodium }(\mathrm{Na}) \\
\text { Potassium }(\mathrm{K}) \\
\text { Bicarbonate }\left(\mathrm{HCO}_{3}\right)^{-}\end{array}$ & 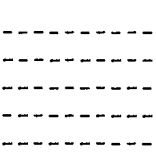 & - n & $\begin{array}{l}7.5 \\
2.5 \\
1.8 \\
1.3 \\
25\end{array}$ \\
\hline $\begin{array}{l}\text { Sulfate }\left(\mathrm{SO}_{4}\right) \\
\text { Chloride }(\mathrm{Cl}) \\
\text { Fluoride }(\mathrm{F}) \\
\text { Nitrate }\left(\mathrm{NO} \mathrm{O}_{3}\right) \\
\text { Boron }(\mathrm{B})\end{array}$ & $\begin{array}{r}7.8 \\
7.8 \\
.1 \\
-\end{array}$ & $\begin{array}{r}55 \\
8.0 \\
.1\end{array}$ & $\begin{array}{l}7.8 \\
1.5 \\
.1 \\
2.2 \\
.08\end{array}$ \\
\hline $\begin{array}{l}\text { Dissolved solids } \\
\text { Hardness as } \mathrm{CaCO} \\
\text { Noncarbonate hardness as } \mathrm{CaCO}_{3} \\
\text { Alkalinity as } \mathrm{CaCO}_{3} \\
\text { Specific conductance (micromhos at } \\
25^{\circ} \mathrm{C} \text { ) }\end{array}$ & $40^{-1}$ & 73 & $\begin{array}{r}84 \\
29 \\
8 \\
21 \\
65.0\end{array}$ \\
\hline $\begin{array}{l}\mathrm{pH} \\
\text { Tulor (units) } \\
\text { Temperatity as } \mathrm{SiO}_{2}\left({ }^{\circ} \mathrm{F}\right)\end{array}$ & $\begin{array}{l}6.3 \\
300 \\
14\end{array}$ & $30^{7.2}$ & $\begin{array}{c}6.7 \\
100 \\
2 \\
52\end{array}$ \\
\hline Date of collection. & \multicolumn{2}{|c|}{ Jan. 17,1956} & Apr. 17, 1958 \\
\hline
\end{tabular}

\section{POTENTIAL WATER SUPPLY}

\section{PRESENT SURFACE-WATER SOURCE}

The rillage of Hoyt Lakes obtains its water supply from the Colby Lake through which the Partridge River flows. The total pumping capacity for the town is $1,575 \mathrm{gpm}$. During high flows of the Partridge River, when Colby Lake is above an altitude of 1,410 feet, water for the Erie Mining Co. taconite plant is pumped from Colby Lake to Whitewater Reservoir and subsequently released to Colby Lake during periods of low flow.

Flow data.-See aurora for Partridge River data.

Quality of Water.-Water from the Partridge River, sampled 0.2 mile west of the Hoyt Lakes map area is similar to that of Colby Lake but has a lower manganese content (table 1). 


\section{OTHER WATER SOURCES}

\section{SURFACE WATER}

No surface-water source other than that of the Partridge River and Colby Lake system seems practical for this location.

\section{GROUND WATER}

Rocks of the Duluth Gabbro Complex underlie the eastern part of the Hoyt Lakes area. These rocks have intruded the argillite and have metamorphosed it at the contact. Because the intrusive rocks and the adjacent metamorphosed argillite are resistant to weathering they form a high bedrock surface (pl. 1). The glacial drift east of area 1 is relatively thin and is composed mainly of gray bouldery till. A morainic ridge composed of this till can be seen extending from the southeast corner of the Hoyt Lakes msp area to the east side of Colby Lake. Neither the bedrock nor the till are adequate sources for a large ground-water supply.

Glacial deposits within area 1 are probably the best source for the development of ground water near Hoyt Lakes. Glacial meltwater drainage, probably controlled by the bedrock high to the east, cut through the moraine at Colby Lake. The melt water eroded the till and laid down sorted deposits of sand and gravel. Although drill-hole samples indicate the glacial drift in area 1 is sand and gravel (pl. 1), surface exposures indicate that it varies from silty bouldery material containing only rudimentary bedding to bedded and well-sorted sand and gravel. The flat-topped hills that border Whitewater Lake probably have the best potential for ground-water development within area 1 . The topography of these hills indicates they are ice-contact deposits of sand and gravel. Test hole $58.15 .24 \mathrm{cac} 1$ on the west edge of Whitewater Lake was drilled into one of these hills. It penetrated 38 feet of permeable sand and gravel between 37 and 75 feet.

The Partridge River, which flows through Colby Lake in area 1, heads about 10 miles northeast of the Hoyt Lakes map area and drains a large area. It is probable that recharge could be induced into the drift from the river and Colby Lake by substantiajly lowering water levels by pumping. Whitewater Lake has been raised by a dam which has increased the saturated thickness of the surrounding drift and increased the total ground-water storage. Large yields could be obtained from ground-water storage as well as from induced infiltration in this part of area 1 . Direct recharge from precipitation is also very high in area 1 as its downward movement is not impeded by the clayey till cover that is present to the west.

$773-321-65-3$ 
Eskers are prominent along the front of the mora ine in sec. 22. Smaller isolated deposits of sand and gravel also ocrur along this front, but are not shown on the map. Probably nore of these deposits are large enough to support large ground-rater developments.

Quality of water.-Water from sand and gravel deposits near Whitewater Lake probably is less colored but contsins more dissolved solids and is harder than water from Colby Iake.

\section{BABBITT}

Population : 2,587

The village of Babbitt is at the extreme eastern end of the Mesabi Range and is the only iron-mining municipalit: on the range that is north of the Giants Range. It has been built since 1950 to serve the taconite industry. North and east of the Laurentian Divide, drainage is northward through Birch Lake by way of the Birch and Dunka Rivers (pl. 1). The drainage from the remainder of the Babbitt map area (pl. 1) is southwestward to the Embarrass River.

The village is underlain by Giants Range Granite which forms the Giants Range ridge in the southern part of the area. The Biwabilk Iron-Formation and the Virginia Argillite lap onto the granite on the south flank of this ridge. A few miles east of the village, these two units are cut by intrusives of the Duluth Gabbro Complex (pl. 1).

The area is covered by a veneer of glacial drift and bedrock exposures are numerous. However, a relatively thick deposit of outwash underlies the village and furnishes ample water to the village wells.

\section{PRESENT WATER SUPPLY}

Source of information: Dennis Orn, treatment plant superinten tent; Minnesota Department of Health records; village records.

Ownership of water supply: Municipal.

Arerage consumption: 200,000 gpd (estimated, 1960).

Number of customers: Approximately 520 (1960).

Storage: Ground-level steel tank, 400,000 gal; elevated steel tank, 150,000 gal.

Treatment: Coagulation with alum, hydrated lime, and activated silica; flltration; chlorination.

Source of supply: Two wells.

Well location 60.13.1bab1. East of water plant 2, at North Jrive and Alden Road; drilled in 1955; 24 inches in diameter; 128 feet deep. Finished between 108 and 128 feet with 24-inch concrete screen; has a $700 \mathrm{gpm}$ turbine pump. Water obtained from glacial sand and gravel. When pumped at 1,162 gpm for 10 hours, water level lowered 13 feet below static water level of 23 feet. 
Well location 60.13.1bba1. In water plant 1, at North Drive and Alden Road; drilled in 1951 but deepened in $1960 ; 16$ inches in diam?ter; 70 feet deep. Finished between 38 and 70 feet with 16-inch concrete screen; has a $600 \mathrm{gpm}$ turbine pump. Water obtained from glacial sand and gravel. When pumped at $600 \mathrm{gpm}$ for 10 hours, water level lorered 32 feet below static water Ievel of 23 feet.

Quality of water.-The water from both wells has a low dissolvedsolids content and is only moderately hard. It is, however, siliceous. Comparison of the analyses on table 3 indicates that, in addition to reducing the iron and manganese content, the water treatment process significantly increases the surfate content, slightly increases the hardness, and decreases the alkalinity of the water. The finished water meets the drinking-water standards of the U.S. Public Health Service (1962).

$\mathrm{T}_{\mathrm{ABLE}}$ 3.-Chemical analyses, in parts per million, of water in the Babbitt vicinity

[Analysis of finished water by the Minnesota Dept. of Health; all othərs by U.S. Geol. Su־vey]

\begin{tabular}{|c|c|c|c|c|c|c|c|c|}
\hline \multirow{4}{*}{$\begin{array}{l}\text { Water source. } \\
\text { Location }\end{array}$} & \multirow{2}{*}{\multicolumn{3}{|c|}{$\frac{\text { Present water supply }}{\text { Ground water }}$}} & \multicolumn{5}{|c|}{ Potential water supply } \\
\hline & & & & & & Surface wat & ter & \\
\hline & \multirow{2}{*}{$\begin{array}{c}\text { Glacial } \\
\text { drift } \\
60.13 .1- \\
\text { bab1 }\end{array}$} & \multirow{2}{*}{$\begin{array}{l}\text { Glacial } \\
\text { drift } \\
60.13 .1- \\
\text { bbal }\end{array}$} & \multirow[t]{2}{*}{ Finished } & \multirow{2}{*}{$\begin{array}{l}\text { Birch } \\
\text { Lake }\end{array}$} & \multicolumn{2}{|c|}{$\begin{array}{c}\text { Dunca River near } \\
\text { Babbitt } \\
\text { Station } 1260\end{array}$} & \multicolumn{2}{|c|}{$\begin{array}{l}\text { Stony Piver near } \\
\text { Isabella i } \\
\text { Station } 1255\end{array}$} \\
\hline & & & & & Average & Maximum & Average & Maximum \\
\hline $\begin{array}{l}\text { Silica }\left(\mathrm{SiO}_{2}\right) \\
\text { Iron }(\mathrm{Fe}) \\
\text { Manganese }(\mathrm{Mn})\end{array}$ & $\begin{array}{r}33 \\
.04 \\
.33\end{array}$ & $\begin{array}{l}29 \\
2.8 \\
.08\end{array}$ & $\begin{array}{r}.08 \\
<.02\end{array}$ & $\begin{array}{l}6.0 \\
.37 \\
.01\end{array}$ & $\begin{array}{r}12 \\
.96 \\
.06\end{array}$ & $\begin{array}{l}17.7 \\
1.7 \\
.28\end{array}$ & $\begin{array}{l}8.1 \\
.55 \\
.05\end{array}$ & $\begin{array}{r}11 \\
.92 \\
.23\end{array}$ \\
\hline $\begin{array}{l}\text { Calcium }(\mathrm{Ca}) \\
\text { Magnesium }(\mathrm{Mg}) \\
\text { Sodium }(\mathrm{Na}) \\
\text { Potassium }(\mathrm{K}) \\
\text { Bicarbonate }\left(\mathrm{HCO}_{3}\right)\end{array}$ & $\begin{array}{r}21 \\
8.9 \\
2.5 \\
104^{.8}\end{array}$ & $\begin{array}{r}20 \\
9.0 \\
2.6 \\
102^{.6}\end{array}$ & 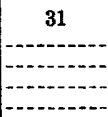 & $\begin{array}{r}7.0 \\
4.0 \\
2.2 \\
31.6\end{array}$ & $\begin{array}{r}7.7 \\
4.7 \\
2.9 \\
1.1 \\
24\end{array}$ & $\begin{array}{l}15 \\
7.4 \\
5.1 \\
1.3 \\
38\end{array}$ & $\begin{array}{l}6.2 \\
3.5 \\
1.4 \\
0.4 \\
30\end{array}$ & $\begin{array}{r}7.8 \\
5.5 \\
1.8 \\
1.1 \\
49\end{array}$ \\
\hline $\begin{array}{l}\text { Sulfate }\left(\mathrm{SO}_{4}\right) \\
\text { Chloride (Cl) } \\
\text { Fluoride (F) } \\
\text { Nitrate (NO } \\
\text { Boron (B) }\end{array}$ & $\begin{array}{l}5.0 \\
1.0 \\
.1 \\
1.0 \\
.01\end{array}$ & $\begin{array}{l}7.5 \\
1.0 \\
.0 \\
.0 \\
.02\end{array}$ & $\begin{array}{r}50 \\
4.0 \\
.16 \\
\hdashline\end{array}$ & $\begin{array}{l}8.8 \\
1.0 \\
.2 \\
1.3 \\
.05\end{array}$ & $\begin{array}{r}11 \\
2.9 \\
12^{.2} \\
.08\end{array}$ & $\begin{array}{l}15 \\
7.7 \\
50.3 \\
.11\end{array}$ & $\begin{array}{c}8.1 \\
.3 \\
.1 \\
1.2 \\
.06\end{array}$ & $\begin{array}{l}13 \\
1.2 \\
.2 \\
2.5 \\
.08\end{array}$ \\
\hline $\begin{array}{l}\text { Dissolved solids } \\
\text { Hardness as } \mathrm{CaC} \mathrm{CO}_{3} \\
\text { Noncarbonate hard- }\end{array}$ & $\begin{array}{r}134 \\
89\end{array}$ & $\begin{array}{r}127 \\
87\end{array}$ & 120 & $\begin{array}{l}83 \\
34\end{array}$ & $\begin{array}{r}121 \\
39\end{array}$ & $\begin{array}{r}219 \\
68\end{array}$ & $\begin{array}{l}82 \\
30\end{array}$ & $\begin{array}{r}122 \\
35\end{array}$ \\
\hline $\begin{array}{l}\text { ness as } \mathrm{CaCO}_{3} \\
\text { Alkalinity as } \mathrm{CaCO}_{3} \\
\text { Percent Sodium }\end{array}$ & $\begin{array}{r}4 \\
85\end{array}$ & $\begin{array}{r}3 \\
84\end{array}$ & 68 & $\begin{array}{r}9 \\
25\end{array}$ & $\begin{array}{l}19 \\
19 \\
14\end{array}$ & $\begin{array}{l}50 \\
31 \\
16\end{array}$ & $\begin{array}{r}5 \\
24 \\
10\end{array}$ & $\begin{array}{l}10 \\
31 \\
14\end{array}$ \\
\hline $\begin{array}{l}\text { Specific conductance } \\
\text { (micromhos at } 25^{\circ} \\
\text { (C) } \\
\text { Color (units) } \\
\text { Turbidity as sio }\end{array}$ & $\begin{array}{l}185 \\
7.3 \\
4 \\
2\end{array}$ & \multirow{2}{*}{$\begin{array}{l}178 \\
7.5 \\
6 \\
20 \\
47\end{array}$} & \multirow[t]{2}{*}{$\begin{array}{c}9.0 \\
10 \\
2.0\end{array}$} & $\begin{array}{c}78 \\
7.2 \\
110\end{array}$ & $\begin{array}{r}88.3 \\
6.3 \\
193\end{array}$ & $\begin{array}{l}172 \\
6.7 \\
250\end{array}$ & $\begin{array}{r}59.8 \\
6.6 \\
138\end{array}$ & $\begin{array}{r}84.5 \\
7.0 \\
220\end{array}$ \\
\hline Temperature $\left({ }^{\circ} \mathrm{F}\right)$ & 47 & & & & 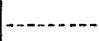 & & & \\
\hline Date of collection. & \multicolumn{2}{|c|}{$\begin{array}{c}\text { Sept. 21, } \\
1956\end{array}$} & $\begin{array}{c}\text { May 20, } \\
1958\end{array}$ & $\underset{1962}{\text { Sept. 26, }}$ & \multicolumn{2}{|c|}{$1955-60$} & \multicolumn{2}{|c|}{$1955-60$} \\
\hline
\end{tabular}

1 Sampling site is 9 miles east of area shown on pl. 1 . 
At the time of the 1956 analyses, well $60.13 .1 \mathrm{bbal}$ ras being used as a standby well. The water was turbid and yellow, although approximately 4,500 gallons was pumped before the simple was obtained. Because the well had not been pumped sincs the previous spring, the color and turbidity probably were greater than if the well had been pumped continuously. The quality of rater from the well may have changed since the well was deepened in 1960.

\section{POTENTIAL WATER SUPPLY}

\section{PRESENT GROUND-WATER SOURCE}

The Vermilion moraine (Wright, 1956, p. 14) crosses the Babbitt map area (pl. 1) from northwest to southeast. Its south edge, or front, forms the north edge of areas 1 and 2. The north edge, or back, of the moraine forms the south shore of Birch Take.

Area 1 is a pitted outwash plain deposited by melt water from the glacier which formed the moraine. The present water supply is obtained from two wells finished in this outwash.

Logs of test holes and wells show the outwash within area 1 to be variable in both thickness and texture. Although the area is very flat and its surface is composed of a gravelly sand, the outwash conceals a very irregular and hilly buried granite surface which in places is covered by a layer of gray bouldery or gray clayey till. In an excavation in the SE1/4 NE1/4 sec. 2, T. $60 \mathrm{~N}$., J. $13 \mathrm{~W}$, , bedrock was observed within 10 feet of the land surface. Auger hole 60.13.3aaa1 terminated at a depth of 26 feet in bedrock or bouldery till. However, village well $60.13 .1 \mathrm{bab1}$ and test hole $60.13 .2 \mathrm{aaa} 2$ bottomed in granite at 127 feet and 201 feet, respective'y.

The grain size of the outwash penetrated in the test holes and wells ranges from very fine silty sand to coarse gravel. The sections containing gravel, which are the most permeable parts of the outwash, are probably lenticular and cannot be correlated by use of existing data.

Village well 60.13 .1 bab1 has a reported specific capacity of $89 \mathrm{gpm}$ per foot of drawdown after 10 hours of pumping at 1,160 gpm. This is very high in comparison to other municipal wells on the Mesabi Range, regardless of the type of aquifer. If that pumping rate could be maintained, this well would produce orer 1.5 million gpd or about 8 times the present consumption.

Ground-water movement in area 1 is away from the Laurentian Divide. North of the divide, movement is toward Birch River. South of the divide, water moves southward toward $t$ ? $?$ narrow belt of small lakes and swamps that forms the southern fart of area 1, and then westward into the headwaters of the Embarrass River. 
Because the divide lies within the area, recharge to the aquifer is limited to local precipitation. However, there is little runoff because of the flat land surface and permeable surficial sand and gravel, and a large part of the precipitation enters the outwash. Ground-water gradients are low, and a large well development could extend the boundaries of the recharge area to the Vermilion moraine and the Giants Range. Area 1 has good potential for the development of additional ground water.

Quality of Water.-The quality of the water for potential supplies from glacial sand and gravel probably is similar to the quality of the water for the present supply.

\section{OTHER WATER SOURCES} GROUND WATER

In the southeast corner of the Babbitt map area (pl. 1) the Dunka River flows through a flat-lying area outlined as area 2. Little drilling has been done in this area, but it is probably uncler? outwash sediments deposited either off the front of the Vermilion Moraine or along the former glacial drainageway now occupied by the Dunka River in secs. 4 and 9. Auger hole 60.12.15abd1 near the river penetrated 50 feet of sand and gravel overlying glacial till.

The recharge area for area 2 is the drainage basin of the Dunka River. It extends south and east of the area shown on plate 1 and includes 5 s square miles. Ground-water movement within t] a area is toward the river. Area 2 is probably a good source of ground water.

The Biwabik Iron-Formation lies about 3 miles south of Babbitt, but it is not an important aquifer in this area. Highly permeable leached ore bodies are not present east of Mesaba because of the thermal metamorphism by the intrusives of the Duluth Gabbro Complex (Gruner, 1956, p. 183, 212). Consequently, the permeability of the iron-formation is low, and ground-water movement through the formation is confined to narrow joints and fractures.

The Giants Range, in the south part of the Babbitt map area, is composed of bedrock with little or no drift cover. North of this, and south of area 1 , the granite bedrock has a very thin drif ${ }^{2}$, cover. Neither area is considered a likely source for large ground-water development.

\section{SURFACE WATER}

The village of Babbitt is about half a mile from Birch Lake into which flow the Dunka and Stony Rivers (pl. 1). Both the Dunka and Stony Rivers have fairly well sustained flows and, used in conjunction with the storage in Birch Lake, would furnish a moderate supply of water. 
DUNTA RIVER NEAR BABBITT, MIINN.

Location.-Lat $47^{\circ} 41^{\prime} 55^{\prime \prime}$, long $91^{\circ} 52^{\prime} 05^{\prime \prime}$, in NW1/4NE1/4 sec. 9, T. 60 N., R. 12 W., on left bank 1.8 miles upstream from Birch Lake and 2.5 miles northeast of Babbitt.

Drainage area.-53.0 square miles.

Records a vailable.-October 1951-September 1960.

Average discharge. -9 years, 37.4 cfs.

Extremes.-1951-60. Maximum discharge, 691 cfs, April 16, 1954 (gage height, $7.84 \mathrm{ft}$ ) ; minimum, $0.7 \mathrm{cfs}$ sometime during period September 12-22, 1960 ; minimum daily discharge, $1.7 \mathrm{cfs}$, February 20, 1958.

Flood frequencr.-10-year flood, $694 \mathrm{cfs} ; 20$-year flood, $846 \mathrm{c} . \mathrm{s} ; 30$-year flood. $998 \mathrm{cfs}$.

Low-flow frequency.-Annual 7-day minimum discharges: 2-5ear, $2.3 \mathrm{cfs} ; 10$ year, $1.1 \mathrm{cfs}$; 20 -year, $0.8 \mathrm{cfs}$; 30 -year, $0.7 \mathrm{cfs}$.

\section{STONY RIVER NEAR ISABELLA, MINN.}

Location.-Lat $47^{\circ} 41^{\prime} 10^{\prime \prime}$, long $91^{\circ} 38^{\prime} 20^{\prime \prime}$, in NW1/4 NW1/4 sec. J.7, T. 60 N., R. 10 W., on left bank 275 feet downstream from Slate Lake and bridge on State Highway 1. 11 miles upstream from Birch Lake, and 12\% miles northwest of Isabella.

Drainage area.--180 square miles.

Records available.-October 1952-September 1960. Prior to O'tober 1958, published as Stony River near Isabella.

Average discharge. -8 years, $138 \mathrm{cfs}$.

Extremes : 1952-60.-Maximum discharge, 2,040 cfs, April 27, 1957 (gage height, $10.60 \mathrm{ft}$ ) ; minimum, $9.0 \mathrm{cfs}$, August 19, 24, 1959, September 26-28, 1960 ; minimum daily discharge, 10 cfs, August 19, 24, 1959, September 23, 26-30, 1960; minimum gage height 7.40 feet September 26-28, 1960.

Flood-frequency.-10-year flood, 1,790 cfs ; 20-year flood, 2,180 cfs; 30-year flood, 2,580 cfs.

Low-flow frequency.-Annual 7-day minimum discharge : 2-years. 17 cfs ; 10-years, 9.4 cfs ; 20 -years, 7.7 cfs ; 30-years, 6.9 cfs.

Quality of water.-The chemical quality of the water available from the Dunka and Stony Rivers is indicated by data in table 3. Water from both streams has a low dissolved-solids content and is soft. However, it is highly colored and contains much iron and, at times, much manganese. Occasionally, water from Dunka River has a high nitrate content.

Water available from the Birch Lake fuctuates lass in quality than water from either of the two streams. The water in the lake is a mixture of water from Dunka River, Stony River, and South Kawishiwi River (table 5), which flows into the northern end of the lake. The lake water, although highly colored, is much less 
colored than water from the Dunka and Stony Rivers, has much less iron, and is nearly free of manganese.

\section{TOWER-SOUDAN}

Population: Tower, 878; Soudan, 777

The city of Tower and the community of Soudan, on the southeast shore of Lake Vermilion, are on the Vermilion Iron Range (pl. 1). The area is drained to the northwest by the East Two River and the West 'Two River into Lake Vermilion, which drains northward into Hudson Bay by way of the Rainy River.

The area is underlain by Ely Greenstone, Soudan Iron-Formation, the Knife Lake Group, and Vermilion Granite. Clements (1903, pl. 2) assigned the granitic rocks in the vicinity of Stuntz Bay to the Laurentian orogeny, but Schwartz (1956, pl. 2) listed th $9 m$ as Algoman. The glacial drift cover is thin and discontinuous, and bedrock exposures are numerous. Tower and Soudan obtain their water from wells completed in glacial drift.

\section{PRESENT WATER SUPPLY}

Source of information: Clarence Williams, water superintendent; E. W. Byrne, water and sewage commission clerk (Town of Breitung) ; Herb Noren, member water and sewage commission (and Soudan mine superintendent); W. A. Cummens, engineer, Oliver Iron Mining Division.

Ownership of water supply: Breitung Township.

Number of customers: Approximately 490 (1960).

Average consumption: 300,000 gpd (estimated, 1960).

Storage: Concrete reservoir, 50,000 gal ; two elevated steel tanks, one of $\mathbf{1 0 , 0 0 0}$ gal and one of 50,000 gal.

Treatment: Polsphosphate stabilization of iron and manganese.

Source of supply : Four wells.

Well location 62.15.33cdd1. Two-tenths of a mile south of Tower Junction depot; drilled in 1961; 8 inches in diameter; 50 feet deep. Finished between 43 and 50 feet with 8-inch wire-wound screen; has a $250 \mathrm{gpm}$ turbine pump. Water obtained from glacial sand and gravel. When pumped at $170 \mathrm{gpm}$ for 3 weeks, water level lowered 18 feet belcw static water level of 4 feet.

Well location $62.15 .33 \mathrm{dbc2}$. One-tenth of a mile east of Tower Junction depot; This auxiliary well drilled in 1947; 12 inches in diameter; 65 feet deep. Finished between 45 and 65 feet with 12 -inch wire-wound screen; has a $250 \mathrm{gpm}$ turbine pump. Water obtained from glacial s9nd and gravel. Pumped at about $125 \mathrm{gpm}$ and static water level about 45 feet below land surface.

Well location 62.15.33dbc3. One-tenth of a mile east of Tower Junction depot; this auxiliary well drilled in 1953 ; 16 inches in diameter ; 66 feet 
deep. Finished between 59 and 66 feet with 16 -inch wire-wound screen; has a $250 \mathrm{gpm}$ turbine pump. Water obtained from glacial sand and gravel. Pumped at about $125 \mathrm{gpm}$ and static water level about 46 feet below land surface.

Well location 62.15.33dbc1. One-tenth of a mile east of Tower Junction depot; this auxiliary well drilled in $1947 ; 12$ inches in diameter; 66 feet deep. Finished between $5 \pm$ and 66 feet with 12-inch wire-wound screen; has a $50 \mathrm{gpm}$ submersible pump. Water obtained from glacial sand and gravel. Pumped at about $40 \mathrm{gpm}$; static water level abjut 46 feet below land surface.

Quality of water.-The analysis for well $62.15 .33 \mathrm{cdd} 1$ (table 4) shows that the water has a moderate dissolved-solids content, is

TABLE 4.-Chemical analyses, in parts per million, of water in the Tower-Soudan vicinity

[Analysis of $62.15 .33 c d d 1$ by the Minnesota Dept. of Health; all others by U.S. Geol. Survey]

\begin{tabular}{|c|c|c|c|c|c|}
\hline \multirow{4}{*}{$\begin{array}{l}\text { Water source... } \\
\text { Location.....-. }\end{array}$} & \multirow{2}{*}{\multicolumn{3}{|c|}{$\frac{\text { Present water supply }}{\text { Ground water }}$}} & \multirow{3}{*}{\multicolumn{2}{|c|}{$\frac{- \text { Potential water supply }}{\text { Surface water }}$}} \\
\hline & & & & & \\
\hline & \multirow{2}{*}{$\mid \begin{array}{l}\text { Glacial drift } \\
62.15 .33 \mathrm{dbc2}\end{array}$} & \multirow{2}{*}{ Glacial drift } & \multirow{2}{*}{ Glacial drift } & & \\
\hline & & & & Average & Maximum \\
\hline $\begin{array}{l}\text { Silica }\left(\mathrm{SiO}_{2}\right) \\
\text { Iron }(\mathrm{Fe}) \\
\text { Manganese }(\mathrm{Mn})\end{array}$ & $\begin{array}{r}13.78 \\
.31\end{array}$ & $\begin{array}{l}13 \\
.25 \\
.38\end{array}$ & $\begin{array}{r}.40 \\
.31\end{array}$ & $\begin{array}{r}\text { 4. } 1 \\
.1 \\
.0\end{array}$ & $\begin{array}{l}5.0 \\
.12 \\
.00\end{array}$ \\
\hline $\begin{array}{l}\text { Calcium }(\mathrm{Ca}) \\
\text { Magnesium }(\mathrm{Mg}) \\
\text { Sodium (Na) } \\
\text { Potassium (K) } \\
\text { Bicarbonate ( } \mathrm{HCO} \text { ) }\end{array}$ & $\begin{array}{l}84 \\
11 \\
6.5 \\
1.5 \\
235\end{array}$ & $\begin{array}{r}77 \\
11 \\
5.3 \\
1.6 \\
227\end{array}$ & $\mid-171^{-1}$ & $\begin{array}{r}9.5 \\
1.7 \\
1.6 \\
27^{.5}\end{array}$ & $\begin{array}{r}\text { 9. } 8 \\
\text { 2. } 1 \\
\text { 1. } 8 \\
31^{.} 6\end{array}$ \\
\hline $\begin{array}{l}\text { Sulfate }\left(\mathrm{SO}_{4}\right) \\
\text { Chloride }(\mathrm{C}) \\
\text { Fluoride (F) } \\
\text { Nitrate }\left(\mathrm{NO}_{3}\right) \\
\text { Boron }(\mathrm{B})\end{array}$ & $\begin{array}{r}65 \\
7.5 \\
.2 \\
.1 \\
.02\end{array}$ & $\begin{aligned} 52 \\
4.2 \\
.1 \\
.1 \\
.02\end{aligned}$ & $\begin{array}{r}41 \\
1.0 \\
.2 \\
\hdashline<1\end{array}$ & $\begin{array}{l}8.9 \\
.0 \\
.1 \\
.7 \\
.03\end{array}$ & $\begin{array}{rl}10 & 0 \\
. & 1 \\
1.0 \\
.03\end{array}$ \\
\hline $\begin{array}{l}\text { Dissolved solids } \\
\text { Hardness as } \mathrm{CaCO} \\
\text { Noncarbonate hardness as }\end{array}$ & $\begin{array}{l}323 \\
253\end{array}$ & $\begin{array}{l}290 \\
236\end{array}$ & 180 & $\begin{array}{l}66 \\
31\end{array}$ & $\begin{array}{l}71 \\
33\end{array}$ \\
\hline $\begin{array}{l}\text { Alkalinity as } \mathrm{CaC} \mathrm{O}_{3} \\
\text { Specific conductance (micro- } \\
\text { mhos at } 25^{\circ} \mathrm{C} \text { ) }\end{array}$ & $\begin{array}{r}60 \\
193 \\
512\end{array}$ & $\begin{array}{r}50 \\
186 \\
467\end{array}$ & $\begin{array}{r}40 \\
140\end{array}$ & $\begin{array}{r}7 \\
22 \\
71\end{array}$ & $\begin{array}{l}8 \\
25 \\
75.4\end{array}$ \\
\hline $\begin{array}{l}\mathrm{pH} \\
\text { Tolor (units) } \\
\text { Temperature }\left({ }^{\circ} \mathrm{F}\right)\end{array}$ & $\begin{array}{l}7.4 \\
3 \\
2 \\
45\end{array}$ & ${ }_{44^{7 .}}^{7}$ & $\begin{array}{c}7.5 \\
15 \\
6\end{array}$ & $4 \overline{8}^{-1}$ & $\begin{array}{c}6.9 \\
65 \\
-10-\end{array}$ \\
\hline Date of collection & June 9 & 1959 & $\begin{array}{c}\text { July } 26 \\
1961\end{array}$ & $\begin{array}{r}3 \text { analys } \\
196\end{array}$ & $\begin{array}{l}\text { es during } \\
0-62\end{array}$ \\
\hline
\end{tabular}


moderately siliceous, is very hard, and contains much iron and manganese. Because the three auxiliary wells are within a 50-foot radius and are about the same depth, water from well $62.15 .33 \mathrm{bdc} 1$ is probably similar in quality to that from $33 \mathrm{dbc} 2$ and 3.

\section{POTENTIAL WATER SUPPLY}

\section{PRESEN'T GROUND-WATER SOURCE}

Within the Tower-Soudan map area (pl. 1), the bedrock is covered by a thin discontinuous veneer of glacial drift. Thicker accumulations of drift are found in: small pockets on the "down glacier" side of bedrock hills, beneath stream valleys, and as small areas of ice-contact deposition. Because of the numerous kadrock highs, the direction of ground-water movement in this area is complex. Recharge from precipitation, which is restricted in its downward percolation by the relatively impermeable bedrosk surface, moves downslope following the bedrock configuration. The irregular bedrock topography results in many small pockets of ground-water accumulation. The ground water in these pockets may be isolated but is generally interconnected and moves toward Lake Vermilion. The connected course of movement toward the lake is commonly represented by a surficial stream valley. The pockets that lie above the level of the streams receive only very local recharge.

Area 1 outlines an isolated esker and a small kame. The three older township wells, 62.15.33dbc1, 2, and 3, are completed in the kame in a section of permeable sand and gravel which over?ies till. (See well 62.15.33dbc2 and pl. 1). Test hole 62.15.33dad1 on the south flank of the esker penetrated 35 feet of sand and grevel between 16 and 51 feet.

Recharge to area 1 is controlled by surrounding bedrock highs and two flanking streams; it is not sufficient to sustain the needs of the two commumities, and continued pumping has drawn the water level down until the unit was nearly dewatered in the early summer of 1961.

Area 2 outlines the wider segments of the valleys of East Two River and West Two River. In an area of thin drift overlying an irregular surface of dense bedrock, the valley of a stream has two distinct advantages for the development of ground water. It is commonly underlain by stratified sediments deposited by glacial or recent drainage, and it receives the maximum available recharge along the entire stream course. 
Within area 2 the drift thickness varies because the bedrock surface is irregular beneath the relatively constant gradient of the valley floor. Test drilling by the township of Breitung has located a narrow zone of permeable sand and gravel within this area. The cross sectional area of this aquifer is much smaller than that of area 1 to the north (pl. 1); however, the aquifer in area 2 is elongate along the course of East Two River and is completely saturated. The main municipal well, 62.15.33cdd1, was pumped from this aquifer at $170 \mathrm{gpm}$ for 3 reeks and had a specific capacity of $9 \mathrm{gpm}$ per foot of drawdown. Although area 2 is the most favorable in the Tower-Soudan vicinity for the development of ground water from glacial drift, it probably cannot sustain large withdrawals.

Quality of Water.-The analyses in table 4 are representative of the quality of water available from areas 1 and 2. Water from area 2 contains less dissolved solids and is not as hard as the water from area 1 , but contains about the same amounts of iron and manganese.

\section{OTHER WATER SOURCES}

GROUND WATER

No other adequate source of ground water is known to exist in the vicinity of Tower-Soudan. The best potential source is adjacent to Lake Vermilion where permeable sand and gravel may extend far enough below lake level so that pumping would induce recharge from the lake. Probably there are few such deposits along the lake shore. None were located during a brief reconnaissance of the surficial geology.

Test holes drilled outside of areas 1 and 2 have indicated potential supplies are small. Township test hole 62.15 .34 baa 1 was drilled into saturated permeable sand and gravel between 20 and 37 feet but did not completely penetrate it. This location is at the south edge of a large bedrock high, and it is unlikely that enough ground water moves through this aquifer to sustain a large-capacity well. Test hole 62.15.35bcc1 penetrated bedrock at a depth of 11 feet; 62.15.33baa1 penetrated 27 feet of sand and gravel batween 18 and 45 feet; and test holes off the sonth flank of the ksme in sec. 33 penetrated varying thicknesses of sand and grarel, most of which were not well sorted and had low permeability.

Bedrock in this area has a low permeability and water can be obtained only from joints and fissures near its surfece. It is not considered a source for large quantities of ground vater. 
SURFACE WATER

Because they are on the shore of Lake Vermilion, Tower and Soudan could obtain an ample water supply from the lake.

\section{FLOW DATA}

VERMILION RIVER BELOW VERMILION LAKE, NEAR TOWER, MINN.

Location.-Lat $47^{\circ} 57^{\prime} 41^{\prime \prime}$, long $92^{\circ} 28^{\prime} 33^{\prime \prime}$, in SE1/4 SE1/4 sec. 2 , T. 63 N., R. 17 W., on left bark 200 feet downstream from dam at 63 N., R. 17 W., on left bank 200 feet downstream from dam at outlet of Vermilion Lake, 4.4 miles unstream from Two Mile Creek, and 14.2 miles northwest of Tower.

Drainage area. 483 square miles.

Records available.-Nay 1911-September 1917; June 1928-Sentember 1960.

Average discharge. -38 years, 303 cfs.

Fxtremes : 1911-17, 1928-60.-Maximum discharge 2,710 cfs, May 23, 1950 (gage height, $4.68 \mathrm{ft}$ ) ; no flow October $25-29,1955$, caused by temporary stowage behind new concrete dam at outlet of Vermilion Lake.

Flood frequency.-10-year flood, $1.920 \mathrm{cfs}$; 20-year flood, 4,620 cfs ; 30-year flood, $5.040 \mathrm{cfs}$.

Quality of water.-Water from Vermilion Lake has low dissolved-solids, iron, and manganese contents and is soft, but it has a considerable amount of color (table 4 ).

\section{ELY}

\section{Population : $\mathbf{5 , 4 3 8}$}

The city of Ely is on the Vermilion Iron Range. Drainage within the Ely map area (pl. 1) is to the northeast, by way of Armstrong Creek, Burntside River, Shagawa Lake, and Shagawa River.

Bedrock in the area is at or near the land surface and consists of Ely Greenstone, Soudan Iron-Formation, the Knife Lake Group, and Giants Range Granite. Glacial drift is patchy and is generally thin. The city obtains its water supply from Burntside Lake.

\section{PRESENT WATER SUPPLY}

Source of information: Anton Pirsh, former treatment plant operator; Steve Preshiren, treatment plant operator; city records.

Ownership of water supply: Municipal.

Number of customers: 1,690 (1960).

Average consumption: 600,000 gpd (estimated, 1960).

Storage: Concrete reservoir, 1,500,000 gal; elevated steel tank, 300,000 gal.

Treatment: Presmmoniation; prechlorination; aeration; addition of lime for corrosion control : fluoridation; filtration; postchlorination. Alum and activated carbon added periodically for coagulation and color and taste control.

Source of supply: Burntside Lake. The pumping station on the sutheast shore of Burntside Lake (63.13.24bad), is equipped with three pumpi having canacities of $750,1,000$, and $1,500 \mathrm{gpm}$. The 1000 and $1500 \mathrm{gnm}$ pumps are auxiliary units. The intake pipe extends 400 feet into the lake and the point of intake is 60 to 70 feet below the lake level. 
Quality of water.-Water from Burntside Lake las a very low dissolved-solids content and is soft. The saturation index of -2.9 indicates that the water is corrosive. The low dissolved-solids content and softness, the almost total absence of iron sind manganese, and the presence of fluoride make the finished water excellent for drinking. (See table 5.)

\section{POTENTIAL WATER SUPPLY}

\section{PRESENT SURFACE-WATER SOURCE}

The domestic water supply for Ely is obtained from Burntside Lake (pl. 1). The maximum pumping capacity is $3,250 \mathrm{gpm}$. Pumping from the present supply could probably bs increased, although in drought years the level of Burntside Lake, has fallen be-

TABLE 5.-Chemical analyses, in parts per million, of water in the Ely vicinity [Analyses by U.S. Geol. Survey]

\begin{tabular}{|c|c|c|c|c|c|c|c|c|}
\hline & \multirow{2}{*}{\multicolumn{2}{|c|}{$\begin{array}{c}\begin{array}{c}\text { Present water } \\
\text { supply }\end{array} \\
\text { Surface water }\end{array}$}} & \multicolumn{6}{|c|}{ Potential wator supply } \\
\hline & & & & & Surfac & vater & . & \\
\hline \multirow[t]{2}{*}{$\begin{array}{l}\text { Water source } \\
\text { Location }\end{array}$} & \multirow{2}{*}{$\begin{array}{c}\text { Burntside } \\
\text { Lake } \\
63.13 .24 \\
\text { bad }\end{array}$} & \multirow[t]{2}{*}{ Finished } & \multicolumn{2}{|c|}{$\begin{array}{c}\text { Bear Island } \\
\text { River near Ely } \\
\text { Station } 1265\end{array}$} & \multicolumn{2}{|c|}{$\begin{array}{c}\text { Kawishiwi } \\
\text { River near Win- } \\
\text { ton }{ }^{2} \\
\text { Station } 1270\end{array}$} & \multicolumn{2}{|c|}{$\begin{array}{l}\text { South Kawishiwi } \\
\text { River near Ely } \\
\text { Station } 1250\end{array}$} \\
\hline & & & $\begin{array}{l}\text { Aver- } \\
\text { age }\end{array}$ & $\begin{array}{l}\text { Maxi- } \\
\text { mum }\end{array}$ & $\begin{array}{l}\text { Aver- } \\
\text { age }\end{array}$ & $\begin{array}{l}\text { Praxi- } \\
\text { mum }\end{array}$ & $\begin{array}{l}\text { Aver- } \\
\text { age }\end{array}$ & $\begin{array}{l}\text { Maxi- } \\
\text { mum }\end{array}$ \\
\hline $\begin{array}{l}\text { Silica }\left(\mathrm{SiO}_{2}\right) \\
\text { Iron ( } \mathrm{Fe}) \\
\text { Manganese }(\mathrm{M} \text { ) }\end{array}$ & $\begin{array}{l}0.8 \\
.03 \\
.00\end{array}$ & $\begin{array}{l}0.9 \\
.04 \\
.00\end{array}$ & $\begin{array}{l}3.7 \\
.37 \\
.00\end{array}$ & $\begin{array}{l}5.4 \\
.56 \\
.00\end{array}$ & $\begin{array}{l}6.0 \\
.31 \\
.01\end{array}$ & $\begin{array}{l}7.5 \\
.43 \\
.02\end{array}$ & $\begin{array}{l}7.3 \\
.44 \\
.05\end{array}$ & $\begin{array}{l}9.8 \\
.70 \\
.23\end{array}$ \\
\hline $\begin{array}{l}\text { Calcium (Ca) } \\
\text { Magnesium (Mg) } \\
\text { Solium (Na) } \\
\text { Potassium (K) } \\
\text { Bicarbonate ( } \mathrm{HCO} \text { ( }\end{array}$ & $\begin{array}{r}3.0 \\
1.6 \\
1.0 \\
13\end{array}$ & $\begin{array}{r}5.4 \\
.9 \\
2.2 \\
16\end{array}$ & $\begin{array}{r}4.6 \\
1.9 \\
1.4 \\
18^{.3}\end{array}$ & $\begin{array}{r}5.2 \\
2.3 \\
1.6 \\
22.8\end{array}$ & $\begin{array}{r}5.3 \\
2.1 \\
1.4 \\
22^{.4}\end{array}$ & $\begin{array}{r}6.9 \\
2.8 \\
1.4 \\
24\end{array}$ & $\begin{array}{r}5.1 \\
2.3 \\
1.5 \\
20^{.4}\end{array}$ & $\begin{array}{l}6.6 \\
2.9 \\
2.0 \\
.8 \\
29\end{array}$ \\
\hline $\begin{array}{l}\text { Sulfate }\left(\mathrm{SO}_{4}\right) \\
\text { Chloride }(\mathrm{Cl}) \\
\text { Fluoride }(\mathrm{F}) \\
\text { Nitrate }\left(\mathrm{NO}_{3}\right) \\
\text { Boron }(\mathrm{B})\end{array}$ & $\begin{array}{l}5.0 \\
.1 \\
.1 \\
.1 \\
.01\end{array}$ & $\begin{array}{l}4.8 \\
1.6 \\
1.1 \\
.4 \\
.05\end{array}$ & $\begin{array}{l}6.5 \\
.1 \\
.1 \\
.9 \\
.03\end{array}$ & $\begin{array}{r}7.3 \\
.5 \\
.2 \\
1.6 \\
.04\end{array}$ & $\begin{array}{r}6.7 \\
.1 \\
.2 \\
.7 \\
-.-0\end{array}$ & $\begin{array}{r}7.8 \\
.1 \\
.2 \\
1.0 \\
.03\end{array}$ & $\begin{array}{l}5.7 \\
.2 \\
.1 \\
.9 \\
.04\end{array}$ & $\begin{array}{r}7.8 \\
.8 \\
.2 \\
1.2 \\
.05\end{array}$ \\
\hline $\begin{array}{l}\text { Dissolved solids } \\
\text { Hardness as } \mathrm{CaC} \mathrm{O}_{3} \\
\text { Noncarbonate hardness as }\end{array}$ & $\begin{array}{l}31 \\
14\end{array}$ & $\begin{array}{l}34 \\
17\end{array}$ & $\begin{array}{l}55 \\
19\end{array}$ & $\begin{array}{l}74 \\
22\end{array}$ & $\begin{array}{l}54 \\
22\end{array}$ & $\begin{array}{l}56 \\
24\end{array}$ & $\begin{array}{l}60 \\
22\end{array}$ & $\begin{array}{l}82 \\
28\end{array}$ \\
\hline $\begin{array}{l}\text { CaCO } \\
\text { Alkalinity as } \mathrm{CaCO}_{3} \\
\text { Percent sodium }\end{array}$ & $\begin{array}{c}3 \\
11 \\
\cdots\end{array}$ & $\begin{array}{r}4 \\
13\end{array}$ & $\begin{array}{r}4 \\
15 \\
14\end{array}$ & $\begin{array}{r}5 \\
18 \\
16\end{array}$ & $\begin{array}{c}4 \\
18 \\
-\cdots\end{array}$ & $\begin{array}{c}4 \\
20 \\
-\end{array}$ & $\begin{array}{r}\mathbf{3} \\
20 \\
13\end{array}$ & $\begin{array}{r}3 \\
25 \\
15\end{array}$ \\
\hline $\begin{array}{l}\text { Specific conductance (micro- } \\
\text { mhos at } 25^{\circ} \mathrm{C} \text { ) } \\
\text { pH } \\
\text { Color (units) } \\
\text { Turbidity as } \mathrm{SiO}_{2} \\
\text { Temperature }\left({ }^{\circ} \mathrm{F} \text { ) }\right.\end{array}$ & $\begin{array}{l}37.2 \\
6.6 \\
7 \\
54\end{array}$ & $\begin{array}{r}50.0 \\
7.2 \\
5 \\
.2 \\
\end{array}$ & $\begin{array}{r}44.2 \\
6.3 \\
79 \\
-\cdots-2 .\end{array}$ & $\begin{array}{c}50.7 \\
6.6 \\
90 \\
0\end{array}$ & $\begin{array}{c}49 \\
64 \\
\end{array}$ & $\begin{array}{c}53 \\
6.7 \\
80\end{array}$ & $\begin{array}{c}49.0 \\
6.7 \\
75\end{array}$ & $\begin{array}{r}61.7 \\
71.0 \\
110\end{array}$ \\
\hline Date of collection. & \multicolumn{2}{|c|}{ June 9,1959} & \multicolumn{2}{|c|}{$1955-60$} & \multicolumn{2}{|c|}{$1959-61$} & \multicolumn{2}{|c|}{$1955-60$} \\
\hline
\end{tabular}

1 Sampling site is 3 miles south of area shown on pl. 1 .

2 Sampling site is 2 miles east of area shown on pl. 1 .

${ }^{3}$ Sampling site is 7 miles southeast of area shown on pl. 1 . 
low the lake outlet into Burntside River. Water for fire protection is obtained from Shagawa Lake.

\section{OTHER WATER SOURCES SURFACE WATER}

Within pumping distance of the city is the Kawishiwi River (see Cotter and others, 1965, fig. 1) which has its headwaters in the numerous lakes south and east of town. A convenient withdrawal point from this river system is White Iron Lake through which it flows and which is within $2 \frac{1}{2}$ miles of downtown Ely.

\section{FLOW DATA}

KAWISHIWI RIVER NEAR WINTON, MINN.

Location.-Lat $47^{\circ} 56^{\prime} 05^{\prime \prime}$, long $91^{\circ} 45^{\prime} 50^{\prime \prime}$, in NE1/4NW'1/4 sec. 20, T. 63 N., R. 11

W., at powerplant of Minnesota Power \& Light Co., just upstream from Fall

Lake, 1.8 miles east of Winton.

Drainage area.-1,200 square miles, approximately.

Records available.-June 1905 to June 1907; October 1912 to September 1919

(fragmentary) ; September 1923 to September 1960.

Average discharge.-41 years $(1905-6,1915-17,1918-19,1923-60)$, §.9 cfs

(unadjusted).

Extremes.-1905-7, 1912-19, 1923-60. Maximum daily discharge, 16,000 cfs

May 18, 1950 ; no fiow at times, regulated.

Remarks.-Flow too much affected by regulation to determine fiood and low fiow frequencies.

Quality of water.-The chemical quality of water from the Kawishiwi River near Winton is shown in table 5. The wator has a low dissolved-solids content and is soft, but it is highly colored and at times has more than the recommended maximum $(0.3 \mathrm{ppm})$ for iron. The water in White Iron Lake is mostly from the South Kawishiwi and Bear Island Rivers, but it probably does not differ significantly in quality from the water in the Kawishiwi River near Winton.

\section{GROUND WATER}

A brief reconnaissance of the Ely vicinity showed that it is underlain by shallow or surficial bedrock, which has low permeability and yields water only from fractures and crevices near the surface. Many domestic supplies are obtained from shallow wells dug or blasted into the bedrock, but the bedrock will not yield enough water to sustain large municipal or industrial wells. Littls subsurface information is available in this area.

The glacial drift in the area consists of thin deposits of gray bouldery till or sand and gravel. These deposits commonly fill depressions between bedrock highs. 
The boundaries of area 1 are based on surficial exposures of ice-contact deposits. The thickest section of glacial drift observed in the Ely vicinity is the eastward-trending ridge which forms the east part of area 1. About 40 feet of ice-contact sand and gravel is exposed in a large gravel pit in the $\mathrm{NE}^{1 / 4}$, of section 35. Area 1 extends westward along the trend of this ridge and includes a sand and gravel deposit within the city. A pit in this deposit penetrates about 30 feet of stratified drift. The total thickness or saturated thickness of these deposits is not known. Gravel pits in the area are dry, and because the bedrock surface is probably shallow, it is doubtful that the saturated thickness is great enough to sustain large capacity wells. Because most of area 1 is a tonographic high, ground-water movement is away from it, and the recharge only occurs locally. If a thick saturated section of sand and gravel were located, lowering the water level by pumping the aquifer would induce some recharge from outside the area. However, the amount induced would be controlled by the configuration of the adjacent near-surface bedrock.

Area 2 outlines drainage courses east and west of Shagawa Lake. Eskers indicate that area 2 was a glacial drainageway and contains coarse stratified drift. The coarsest materials are found in the kames and eskers. Where most of these units are saturated, large supplies of water are available. Generally, the saturated thickness is small; it is probably greatest in the western part of the area 2.

Auger holes 63.12.23acc1, 2, and 3, 23bdd1, and 23dbc1, at the northeast end of Shagawa Lake, show that bedroc's is 11 feet or less below the land surface. About half a mile east of the Ely map area, along the trend of area 2 , test holes penetrated as much as 16 feet of water-bearing sand and gravel to a maximum depth of 38 feet.

Local ground-water movement is into area 2, and the potential recharge from the rivers and lakes is very good. This area has the best potential for the development of ground water within the Ely vicinity, but hydrologic and geologic testing would be necessary to locate a thick section of saturated permeable sand and gravel.

Except for areas 1 and 2, most of the Ely vicinity is bedrock and probably will yield very little water.

\section{LITERATURE CITED}

Clements, J. M., 1903, The Vermilion iron-bearing district of Minnesota: U.S. Geol. Survey Mon. 45, $463 \mathrm{p}$.

Cotter, R. D., Young H. L., Petri, L. R., and Prior, C. H., 1965, Ground and surface water in the Mesabi and Vermilion Iron Range area, northeastern Minnesota: U.S. Geol. Survey Water-Supply Paper 1759-A. 
Goldrich, S. S., Nier, A. O., Baadsgaard, Halfdan, Hoffman, J. H., and Krueger, H. W., 1961, The precambrian geology and geochronology of Minnesota: Minnesota Geol. Survey Bull. 41, 193 p.

Gruner, J. W., 1956, The Mesabi Range, in Precambrian of northeastern Minnesota: Geol. Soc. America Guidebook Ser., Minneapolis Mtg., p. 182--215.

Henderson, J. R., and Meuschke, J. L., 1952, Total intensity aeromagnetic and geologic map of part of southeastern St. Louis County, Minnesota: U.S. Geol. Survey Geophys. Inv. Map GP-92.

Schwartz, G. M., ed., 1956, Precambrian of northeastern Minnesota: Geol. Soc. America Guidebook Ser., Minneapolis Mtg., 235 p.

U.S. Public Health Service, 1962, Drinking Water Standards, 1962: Public Health Service pub. 956, 61 p., Washington, U.S. Govt. Printing Office, 61 p.

White, D. A., 1954, The stratigraphy and structure of the Mesabi Range, Minnesota: Minnesota Geol. Survey Bull. 38, $92 \mathrm{p}$.

Wright, H. E., 1956, Landforms and glacial history of northeastern Minnesota, in Precambrian of northeastern Minnesota: Geol. Soc. America Guidebook Ser., Minneapolis Mtg., p. 10-19. 